\title{
CYTOLOGICAL CHARACTERIZATION OF SOME COWPEA (VIGNA UNGUICULATA L.) ACCESSIONS
}

\author{
HASSAN A.H. SOLTAN ${ }^{1}$, SAYED A.M. OSMAN ${ }^{2^{*}}$ \\ ${ }^{1}$ Central Lab. of Organic Agriculture, ARC, Giza 12619, Egypt, ${ }^{2}$ Department of Genetics, Faculty of \\ Agriculture, Minia University, El Minia, Eg-61519, Egypt \\ *Corresponding Author: sayed.osman@ mu.edu.eg
}

Received on: 11-3-2021

Accepted on: 19-4-2021

\begin{abstract}
Studying the cytological behavior of twenty seven cowpea (Vigna unguiculata L.) accessions to select new promising ones which could be used in cowpea breeding programs were carried out in the present investigation. All tested cowpea accessions exhibited the same normal chromosome number $2 n=22$. The means of mitotic index (MI) were significantly different among most of studied accessions and some accessions exhibited high variability in the percentage values of mitotic stages. From all tested cowpea accessions, few of them showed high frequency of total mitotic chromosomal aberrations. Various types of mitotic abnormalities such as; lagging chromosomes, chromosomal bridges, outside chromosome, stickiness and micronuclei have been observed in all tested accessions. The cytological findings revealed that most of tested cowpea accessions had a potential cytological stability with normal chromosomal number $2 \mathrm{n}=22$ and could be considered as good basic tools in cowpea breeding programs.
\end{abstract}

KEYWORDS: Cowpea, Mitotic index, Mitotic aberrations, Plant breeding

\section{INTRODUCTION}

Cowpea (Vigna unguiculata L. Walp) is considered as one of the most important legume crops in Egypt and other tropic and sub-tropic countries (Damarany,1994, and Singh, 2012). In Egypt, cowpea cultivation area according to FAOSTAT, 2018 was about 1840.86 Hectares with production of about 7108 tons with (an average yield of 3.86 ton/ Hectares). It is grown in Egypt both as vegetable and plus corps. In addition to, it is favorable to the Egyptian consumers especially in form of dry seeds. This legume can also be a major source of protein (22-24\%), carbohydrate (50-67 $\%)$, starch, vitamins and minerals as unripe pods or dry seeds (Pavadai et al., 2009) and as fodder (Baudoin and Marechal, 2001 and Tarawali et al ., 2002). Because of many people cannot afford protein foods such as meat and fish they used cowpea as primary and cheap protein sources (Rivas-Vega et al., 2006 and Akpapunam and SefaDedeh, 1997). In addition to the value of cowpea as food and fodder, it is a valuable component of farming systems in many areas because of its ability to restore soil fertility for succeeding cereal crops grown in rotation with it (Timko and Singh, 2008).

Cowpea is a diploid species with $2 \mathrm{n}=2 \mathrm{x}=22$ chromosomes, belongs to the family Leguminosae (Verdcourt, 1970). At the cellular level, plant growth and development are resulted from three general processes: cell division (mitosis), cell expansion and cell differentiation (Wang and Ruan, 2013). The continuous addition of new germplasm material as a donor for various useful genes of the agronomic traits is an important process for further improvement of cowpea cultivars especially as there are concerning that the yield peaks in major crops species including cowpea have been reached. Landraces of cowpea can undoubtedly contribute towards the development of germplasm pools (Willie and Aikpokpodion, 2015).

Cell division or mitosis and cell expansion determine cell number and cell size in a mature organ hence its yield (Wang and Ruan, 2013). The mitotic index of a cell population has long been regarded as an important criterion for the growth and multiplication of the cells and tissues. One of the reasons for the mitotic indexing of species is to generate data which is important for breeding purposes (Darbelley et al., 1989 and Driss-Ecole et al., 1994). On the other side, chromosomal abnormalities have been used as a good tool to measure the success of the reproduction in plants for many years and it is correlated with the morphological and taxonomical modifications, fertility-sterility relationships, mutations, and other characteristics (Grant, 1978). So, the aim of this present work is to evaluate the cytological behavior of twenty seven cowpea accessions which could be used in plant improvement programs as promising cowpea accessions in Egypt. 


\section{Scientific Journal of Agricultural Sciences 3 (1): 131-136, 2021}

\section{MATERIALS AND METHODS}

\subsection{PLANT MATERIAL}

Seeds of twenty seven accessions of cowpea have been kindly obtained from Horticulture Dept., Faculty of agriculture, Minia university, Minia Governorate, Egypt.

\subsection{CYTOLOGICAL STUDIES}

This study was carried out at Cytogenetics lab., Genetics Dept., Fac. Agri., Minia Uni. Seeds of twenty seven genotypes of cowpea were germinated in Petri dishes containing two layers of moist filter paper at room temperature for 48 hours. Roots with $1-2 \mathrm{~cm}$ in length were cut and fixed in freshly prepared farmer's fixative solution (absolute ethyl alcohol: glacial acetic acid, 3:1 v/v) for 24 hours. Fixed roots were kept in $70 \%$ ethyl alcohol in the refrigerator until use. Treated roots were washed with distilled water, hydrolyzed in $1 \mathrm{~N} \mathrm{HCl}$ at $60{ }^{\circ} \mathrm{C}$ for 10 minutes then washed by distilled water again. The aceto-carmine squash preparation was used for mitotic studies. More than 1000 cells were examined for each genotype (consisting of ten seeds). Photographs were taken wherever necessary using Olympus BX51 microscope with a C-4040 zoom digital camera. Mitotic index, phase index and chromosomal abnormalities were recorded in each genotype and mitotic index was calculated using the following formula as described by Racuciu (2009):

$$
\text { Mitotic index }=\frac{\text { Total Number of Divided Cells }}{\text { Total Number of Examined Cells }} \times 100
$$

Percentage of abnormality of each stage of mitosis was counted for each slide.

$$
\text { Percentage of Abnormality }=\frac{\text { Total Number of Abnormal Cells }}{\text { Total Number of Examined Cells }} \times 100
$$

Cytological data were statistically analyzed using MSTAT program (Version 4) according to Gomes and Gomes (1984).

\section{RESULTS AND DISCUSSION}

\subsection{CYTOLOGICAL STUDIES}

\subsubsection{MITOTIC INDEX (MI)}

The mean percentages of phase and mitotic index (MI) have been recorded in root meristematic cells of twenty seven cowpea accessions were shown in Table (1). Data showed that the mean percentages of MI ranged from (2.39 to $4.53 \%$ ). The accessions 1 and 2 gave the highest value of MI (4.53\%) while the accession 12 gave the lowest value $(2.39 \%)$. Generally, the percentages of MI were nearly close except those of accessions 1 and 2 with the same value $(4.53 \%)$ and $14(4.31 \%)$ which have a significant variation with almost all other accessions. Concerning prophase index data in Table 1, there were a considerable variations in prophase index among all tested accessions. On the same side, the accession no. 6 gave the highest percentage of prophase index $(44.60 \%)$ with a significant increase with almost all other accessions. On the other hand, accession no. 16 gave the lowest percentage $(14.94 \%)$. Generally, the percentages of metaphase index values were higher than other phases. The accession no. 7 gave the highest value of metaphase index $(66.23 \%)$ while accession 6 gave the lowest value $(39.84 \%)$ as compared with all other accessions.

The accession no. 6 gave the lowest value of metaphase index (39.84\%) when compared with all other accessions. The anaphase and telophase index appeared in low frequency as compared with other phases except in accession no. $16(32.13 \%)$ which was more than its prophase index (14.94\%). The chromosome number $2 \mathrm{n}=22$ which recorded in this study is consistent with the earlier reports of $2 n=22$ for $V$. unguiculata and some related wild species (Damayanti et al., 2010 and Shambhu, 2013).

Studying the mitotic parameters such as: mitotic index and mitotic abnormalities allowed a preliminary figure about cytogenetic variations among the genotypes of interest to be drawn. Mitotic index is considered a parameter that allows to estimate the frequency of cellular division (Marcano et al., 2004 and Leme and MarinMorales, 2009). The means of mitotic index (MI) were significantly different among most of studied accessions and some accessions exhibited high variability in the percentage values of mitotic stages. This might be due to differences in genetic control systems of mitosis (cell cycle program) and/or the quantity of somatic mutations (Yasuhara and Shibaoka, 2000 and Osman and Mustafa, 2009). 
Table 1. Percentages of phase and mitotic index (MI) obtained from root tips of twenty seven cowpea Vigna unguiculata $\mathrm{L}$. accessions.

\begin{tabular}{|c|c|c|c|c|c|c|}
\hline Accessions & $\begin{array}{c}\text { T.no. } \\
\text { examined } \\
\text { cells }\end{array}$ & $\begin{array}{c}\text { T.no. } \\
\text { divided } \\
\text { cells }\end{array}$ & $\begin{array}{c}\text { Prophase } \\
\%\end{array}$ & Metaphase \% & $\begin{array}{c}\text { Ana } \\
\text { \&Telophase \% }\end{array}$ & $\begin{array}{r}\text { Mitotic } \\
\text { index \% }\end{array}$ \\
\hline $\mathbf{1}$ & 1172 & 53 & 33.46 & 47.38 & 19.16 & 4.53 \\
\hline 2 & 1165 & 52 & 27.80 & 52.11 & 20.09 & 4.53 \\
\hline 3 & 1234 & 47 & 24.97 & 54.19 & 20.84 & 3.80 \\
\hline 4 & 1151 & 39 & 36.84 & 40.24 & 22.92 & 3.41 \\
\hline 5 & 1220 & 32 & 30.22 & 50.91 & 18.86 & 2.63 \\
\hline 6 & 1108 & 28 & 44.60 & 39.84 & 15.56 & 2.56 \\
\hline 7 & 1182 & 32 & 18.53 & 66.23 & 15.24 & 2.75 \\
\hline 8 & 1153 & 30 & 18.34 & 57.04 & 24.61 & 2.63 \\
\hline 9 & 1210 & 40 & 23.79 & 60.66 & 15.55 & 3.33 \\
\hline 10 & 1347 & 34 & 25.64 & $\mathbf{5 3 . 5 7}$ & 20.80 & 2.51 \\
\hline 11 & 1383 & 38 & 29.80 & 50.34 & 19.87 & 2.75 \\
\hline 12 & 1455 & 35 & 23.25 & 60.63 & 16.13 & 2.39 \\
\hline 13 & 1359 & 39 & 25.46 & 55.92 & 18.62 & 2.84 \\
\hline 14 & 1364 & 59 & 29.94 & 43.84 & 26.22 & 4.31 \\
\hline 15 & 1267 & 45 & 26.63 & 54.09 & 19.28 & 3.53 \\
\hline 16 & 1149 & 30 & 14.94 & 52.93 & 32.13 & 2.64 \\
\hline 17 & 1004 & 26 & 30.95 & 50.63 & 18.41 & 2.58 \\
\hline 18 & 1548 & 40 & 26.30 & 58.56 & 15.15 & 2.62 \\
\hline 19 & 1240 & 41 & 35.96 & 51.89 & 12.15 & 3.31 \\
\hline 20 & 1378 & 35 & 24.30 & 51.87 & 23.54 & 2.56 \\
\hline 21 & 1046 & 29 & 19.22 & 55.07 & 25.70 & 2.75 \\
\hline 22 & 1189 & 37 & 25.48 & 58.24 & 16.28 & 3.13 \\
\hline 23 & 1308 & 33 & 20.39 & 52.09 & 27.52 & 2.53 \\
\hline 24 & 1171 & 35 & 18.46 & 61.33 & 20.21 & 2.96 \\
\hline 25 & 1002 & 36 & 25.87 & 44.51 & 19.16 & 3.56 \\
\hline 26 & 1139 & 37 & 33.20 & 52.34 & 20.09 & 3.30 \\
\hline 27 & 1160 & 29 & 22.55 & 53.79 & 23.67 & 2.49 \\
\hline $\mathbf{L S D}_{0.05}$ & & & 12.93 & 12.57 & 12.28 & 1.45 \\
\hline
\end{tabular}

\subsubsection{MITOTIC ABNORMALITIES}

Different types of mitotic abnormalities such as; lagging chromosomes, chromosomal bridges, outside chromosome, stickiness and micronuclei have been recorded and shown in Table (2) and Figure (1). Results showed that the three accessions 22, 9 and 27 gave the highest values of total mitotic abnormalities (7.26, 6.61 and $6.32 \%$, respectively) while the two accessions 14 and 10 gave the lowest values $(0.93$ and $1.01 \%$, respectively) as compared with all other accessions. The remaining accessions suffered from abnormalities ranged from 1.43 to $5.77 \%$. According to the data in Table 2 the two accessions 20 and 12 have the highest frequencies of chromosomal bridges $(2.11$ and $2.06 \%$, respectively) as compared with the other tested accessions. The outside chromosome was found in almost all tested cowpea accessions. It is appeared with high frequencies in accessions no. 17 and 16 (4.52 and $3.33 \%$, respectively) with significant variations with all most all other accessions. Concerning chromosomal stickiness percentages, results revealed that the four genotypes $22,27,19$ and 21 gave the highest values $(4.58,4.24,4.06$ and $3.61 \%$, respectively) as compared with all other tested accessions. Laggard chromosomes were only found in seven accessions (2, 4, 8, 9, 12, 18 and 26 at low frequencies. From all mitotic aberration scored in this experiment the percentage of micronuclei was the lowest value as compared with all other mitotic aberrations. It is found only in two genotypes 4 and 8 with a very low values $(0.14$ and $0.12 \%$, respectively).

The formation of bridges could be attributed to chromosomal breakage and reunion (Nassif et al., 2009). Stickiness represented the most common types of mitotic abnormalities. Stickiness might be caused by chromosomes folding together and the chromosomes become compacted to each other by sub chromatid bridges (Khanna and Sharma, 2013). 
Table 2. Percentages of total mitotic abnormalities obtained from root tips of twenty seven cowpea Vigna unguiculata $\mathrm{L}$. accessions.

\begin{tabular}{cccccccc}
\hline Accessions & $\begin{array}{c}\text { T. no. of } \\
\text { examined } \\
\text { cells }\end{array}$ & $\begin{array}{c}\text { Bridges } \\
\text { \% }\end{array}$ & $\begin{array}{c}\text { Outside } \\
\text { \% }\end{array}$ & $\begin{array}{c}\text { Stickiness } \\
\text { \% }\end{array}$ & $\begin{array}{c}\text { Laggards } \\
\text { \% }\end{array}$ & $\begin{array}{c}\text { Micro } \\
\text { nuclei } \\
\text { \% }\end{array}$ & $\begin{array}{c}\text { T. } \\
\text { Abnormalities } \\
\text { \% }\end{array}$ \\
\hline $\mathbf{1}$ & $\mathbf{1 1 7 2}$ & 0.00 & 0.72 & 0.71 & 0.00 & 0.00 & 1.43 \\
$\mathbf{2}$ & $\mathbf{1 1 6 5}$ & 0.00 & 1.19 & 0.00 & 0.74 & 0.00 & 1.93 \\
$\mathbf{3}$ & $\mathbf{1 2 3 4}$ & 0.98 & 0.98 & 0.48 & 0.00 & 0.00 & 2.44 \\
$\mathbf{4}$ & $\mathbf{1 1 5 1}$ & 1.11 & 1.68 & 1.68 & 1.11 & 0.14 & 5.57 \\
$\mathbf{5}$ & $\mathbf{1 2 2 0}$ & 1.15 & 0.00 & 0.68 & 0.00 & 0.00 & 1.83 \\
$\mathbf{6}$ & $\mathbf{1 1 0 8}$ & 1.96 & 0.00 & 0.00 & 0.00 & 0.00 & 1.96 \\
$\mathbf{7}$ & $\mathbf{1 1 8 2}$ & 0.81 & 0.90 & 0.00 & 0.00 & 0.00 & 1.71 \\
$\mathbf{8}$ & $\mathbf{1 1 5 3}$ & 0.00 & 0.88 & 1.01 & 1.01 & 0.12 & 2.90 \\
$\mathbf{9}$ & $\mathbf{1 2 1 0}$ & 0.93 & 2.66 & 2.10 & 0.93 & 0.00 & 6.61 \\
$\mathbf{1 0}$ & $\mathbf{1 3 4 7}$ & 0.00 & 0.00 & 1.01 & 0.00 & 0.00 & 1.01 \\
$\mathbf{1 1}$ & $\mathbf{1 3 8 3}$ & 1.83 & 0.00 & 0.00 & 0.00 & 0.00 & 1.83 \\
$\mathbf{1 2}$ & $\mathbf{1 4 5 5}$ & 2.06 & 0.00 & 1.96 & 0.98 & 0.00 & 5.00 \\
$\mathbf{1 3}$ & $\mathbf{1 3 5 9}$ & 1.90 & 0.95 & 0.85 & 0.00 & 0.00 & 3.71 \\
$\mathbf{1 4}$ & $\mathbf{1 3 6 4}$ & 0.51 & 0.42 & 0.00 & 0.00 & 0.00 & 0.93 \\
$\mathbf{1 5}$ & $\mathbf{1 2 6 7}$ & 0.00 & 1.21 & 0.85 & 0.00 & 0.00 & 2.07 \\
$\mathbf{1 6}$ & $\mathbf{1 1 4 9}$ & 0.00 & 3.33 & 1.11 & 0.00 & 0.00 & 4.44 \\
$\mathbf{1 7}$ & $\mathbf{1 0 0 4}$ & 0.00 & 4.52 & 0.00 & 0.00 & 0.00 & 3.33 \\
$\mathbf{1 8}$ & $\mathbf{1 5 4 8}$ & 0.67 & 0.00 & 0.98 & 0.98 & 0.00 & 2.63 \\
$\mathbf{1 9}$ & $\mathbf{1 2 4 0}$ & 0.00 & 1.11 & 4.06 & 0.00 & 0.00 & 5.17 \\
$\mathbf{2 0}$ & $\mathbf{1 3 7 8}$ & 2.11 & 0.72 & 0.95 & 0.00 & 0.00 & 3.79 \\
$\mathbf{2 1}$ & 1046 & 0.00 & 2.16 & 3.61 & 0.00 & 0.00 & 5.77 \\
$\mathbf{2 2}$ & $\mathbf{1 1 8 9}$ & 0.00 & 2.68 & 4.58 & 0.00 & 0.00 & 7.26 \\
$\mathbf{2 3}$ & $\mathbf{1 3 0 8}$ & 0.00 & 2.09 & 0.98 & 0.00 & 0.00 & 3.07 \\
$\mathbf{2 4}$ & $\mathbf{1 1 7 1}$ & 0.00 & 0.76 & 1.95 & 0.00 & 0.00 & 2.71 \\
$\mathbf{2 5}$ & $\mathbf{1 0 0 2}$ & 0.85 & 0.00 & 1.86 & 0.00 & 0.00 & 2.72 \\
$\mathbf{2 6}$ & $\mathbf{1 1 3 9}$ & 0.00 & 1.67 & 2.67 & 1.04 & 0.00 & 5.38 \\
$\mathbf{2 7}$ & $\mathbf{1 1 6 0}$ & 1.08 & 1.01 & 4.24 & 0.00 & 0.00 & 6.32 \\
$\mathbf{L S D}$ & & $\mathbf{2 . 3 6}$ & $\mathbf{2 . 9 7}$ & $\mathbf{2 . 8 9}$ & $\mathbf{1 . 4 2}$ & $\mathbf{0 . 0 2}$ & $\mathbf{5 . 0 2}$ \\
\hline & & & & & & & \\
\hline
\end{tabular}

Outside chromosomes could be attributed to the failure of the spindle apparatus to organize and function in a normal way rather than inhibition of these spindle fibers and this may lead to irregular orientation of chromosomes (Kumar and Rai, 2007).

The high percentages of mitotic chromosomal abnormalities which found in some of our tested accessions could be attributed to that these genotypes are recently imported and cultivated under new environmental conditions in Egypt. Similar results were found by Osman and Mustafa, 2009 when they evaluated the horticultural behavior and cytogenetical profiles of some local and foreign garlic genotypes in Egypt.

\section{REFERENCES}

Akpapunam MA, Sefa-Dedeh S (1997). Jack bean (Canavalia ensiformis): Nutrition related aspects and needed nutrition research. Plant foods for human nutrition 50(2): 93-99.

Baudoin JP, Marechal R (2001). Genetic diversity in Vigna. In: Singh S.R. and Rachie K.O. (eds),
Cowpea research, production and utilization. John Wiley \& Sons, Chichester pp. 3-11.

Damarany AM (1994). Testing and screening of some cowpea (Vigna unguiculata (L) Walp) genotypes under Assiut condition. Assiut Jour. of Agric. Sci. 25(4): 9-19.

Damayanti F, Lawn RJ, Bielig LM (2010). Genetic compatibility among domesticated and wild accessions of the tropical tuberous legume Vigna vexillata (L.) A. Rich. Crop and Past Sci. 61(10): 785-797.

Darbelley ND, Driss-Ecole D, Perbal G (1989). Elongation of Mitotic Activity of Lentil Roots Grown in Micro- gravity. Plant Physiological Biochemistry 27: 341-347.

Driss-Ecole D, Schoevaert DD, Noin M, Perbal G (1994). Densitomeric Analysis of Nuclear DNA Content in Lentil Roots Grown in Space. The Cell, 81: 59-64.

Gomes KA, Gomes AA (1984). Statistical procedures of agricultural research. John Willy\& Sons, New York. 
A

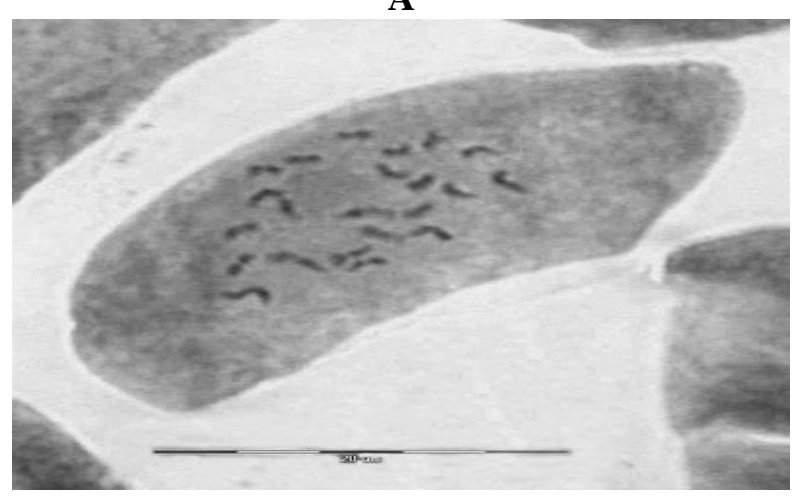

C

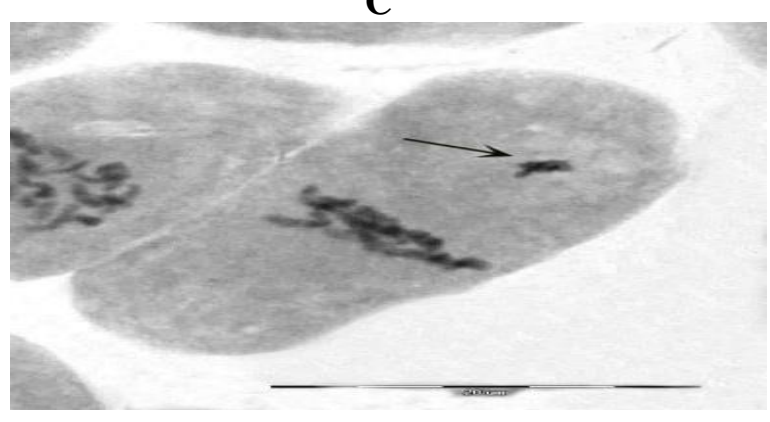

$\mathbf{E}$

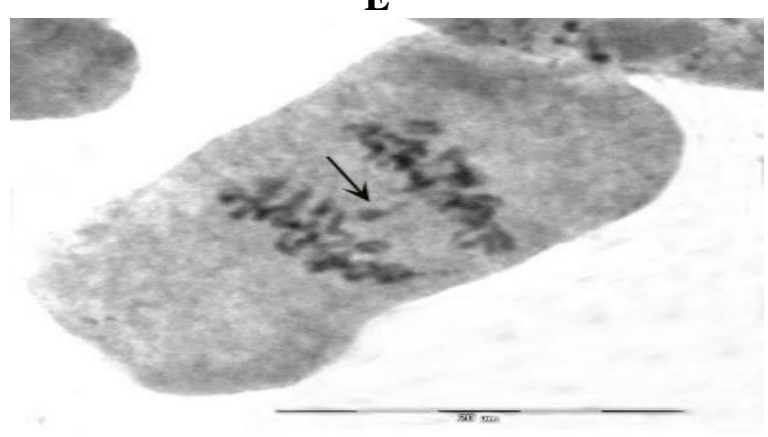

B

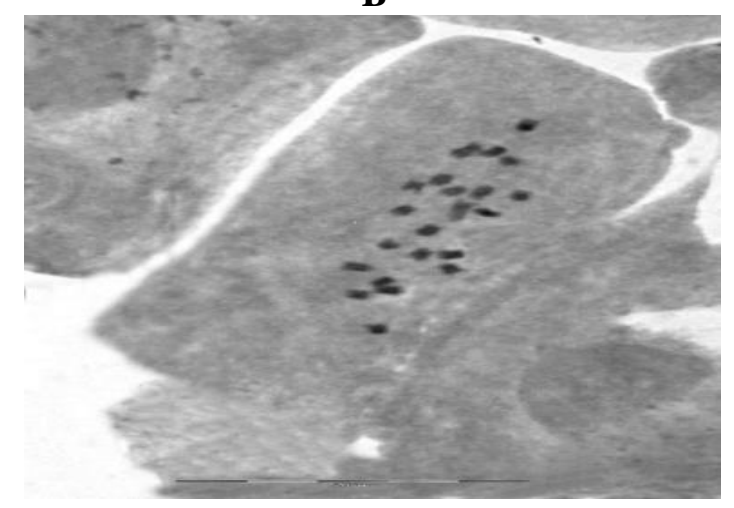

D

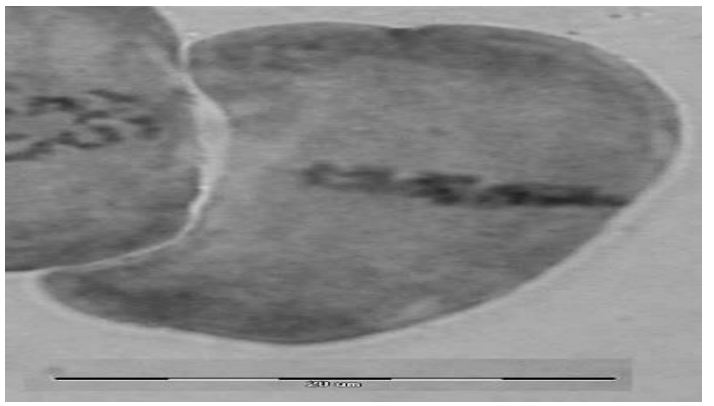

$\mathbf{F}$

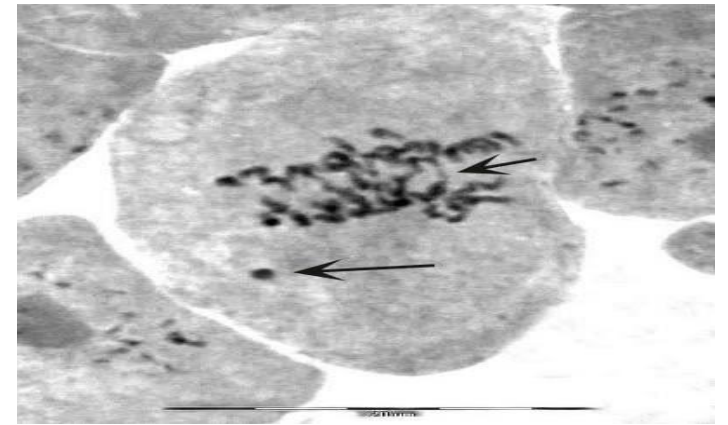

Fig 1. Some of chromosomal abnormalities at different mitotic stages observed in meristemic cells of twenty seven cowpea accessions: (A and B) normal metaphase, $2 \mathrm{n}=22$ (C) outside chromosome at metaphase, (D) chromosomal stickiness at metaphase, (E) lagging chromosome at anaphase, (F) micronuclei and bridge at anaphase. Scale bar $=20$ microns

Grant WF (1978). Chromosome Aberrations in Plants as a Monitoring System. Environmental Health Perspectives 27: 37-43.

Khanna N, Sharma S (2013). Allium Cepa Root Chromosomal Aberration Assay: A Review 1: 105119.

Kumar G, Rai PK (2007). EMS Induced Karyomorphological Variations in Maize (Zea mays L.) Inbreds. Turk J Biol. 31: 187- 195.

Leme DM, Marin-Morales MA (2009). Allium cepa test in environmental monitoring: A review on its application. Mutation Research 682(1):71-81.

Marcano L, Carruyo I, Del Campo A, Montiel X (2004). Cytotoxicity and mode of action of maleic hydrazide in root tips of Allium cepa L. Environmental Research 94: 221-226.

Nassif FA, Ata AM, El-Mamlouk EA, Soltan HAH (2009). Genotoxicity of some synthetic and bio-fungicides on Vicia faba and the yeast tester strain (D7). Egypt. J. Agric. Res. 87: 301-315.

Osman SAM, Moustafa YMM (2009). Horticultural and cytogenetical characteristics of some Egyptian and foreign garlic cultivars. African Crop Science Conference Proceedings 9: 459-465.

Pavadai P, Girija M, Dhanavel D (2009). Effectiveness, efficiency and biochemical content of physical and chemical mutagens in soybeans 
(Glycine Max (L.) Merr.). Journal of Phytology 1(6):444-447.

Racuciu M (2009). Effect of radiofrequency radiation on root tip cells of Zea mays . Roum. Biotechnol. Lett. 14 (3): 4365-4369.

Rivas-Vega ME, Goytortúa-Bores E, EzquerraBrauer JM, Salazar-García MG, Cruz-Suárez LE, Nolasco H, Civera-Cerecedo $R$ (2006). Nutritional value of cowpea (Vigna unguiculataL. Walp) meals as ingredients in diets for Pacific white shrimp (Litopenaeus vannamei Boone). Food Chemistry 97(1):41-49.

Shambhu B (2013). Studies on flower visitors of field bean Lablab purpureus (L.) sweet and their role in pollination and pod set (Doctoral dissertation).

Singh BB (2012). Breeding Diverse, Durable, and Diet-Plus Cowpea Varieties for Increased Cowpea Production and Enhanced Nutrition and Health in the 21stCentury. In: Boukar, O., Coulibaly, O., Fatokun, C.A., Lopez, K. and Tamo, M., Eds., Innovative Research along the Cowpea Value Chain. Proceedings of the Fifth World Cowpea Conference on Improving Livelihoods in the Cowpea Value Chain through Advancement in Science, Saly, 27 September -1 October 2010, International Institute of Tropical Agriculture (IITA), Ibadan, 17-29.
Tarawali SA, Singh BB, Gupta SC, Tabo R, Harris F, Nokoe S, Fernández-Rivera S, Bationo A, Manyong VM, Makinde K, Odion EC (2002). Cowpea as a key factor for a new approach to integrated crop livestock systems research in the dry savannas of West Africa. International Institute of Tropical Agriculture, Ibadan, Nigeria pp 233-251.

Timko MP, Singh BB (2008). Cowpea, a multifunctional legume. In: Moore, P. H. and Ming, R. (eds.). Genomics of Tropical Crop Plants. Springer, New York pp. 227-256.

Verdcourt B (1970). Studies in the LeguminosaePapilionoideae for 'Flora of Tropical East Africa': IV. Kew Bul. 24: 507-569.

Wang L, Ruan YL (2013). Regulation of Cell Division and Expansion by Sugar and Auxin Signalling.Frontiers in Plant Science 4:163.

Willie PO, Aikpokpodion PO (2015). Mitotic Activity in Cowpea (Vigna unguiculata (L.) Land Race "Olaudi" Walp)in Nigeria. American Journal of Plant Sciences 6:1201-1205.

Yasuhara H, Shibaoka H (2000). Inhibition of Cell-Plate Formation by Brefeldin Inhibited the Depolymerization of Microtubules in the Central Region of the Phragmoplast. Plant Cell Physiology 41: 300-310.

\section{الملخص العربي \\ (VIGNA UNGUICULATA L.) التوصيف الخلوي لبعض التراكيب الوراثية من اللوبيا

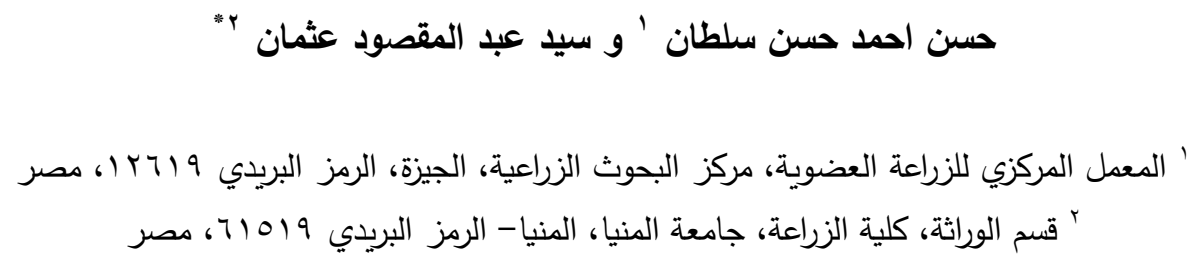

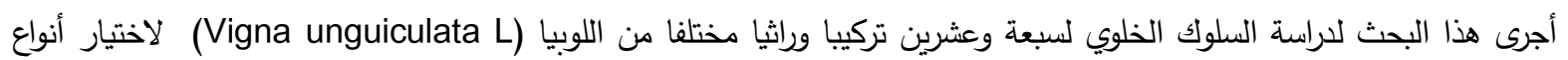
واعدة منها لاستخدامها كمصادر وراثية جديدة في برامج تربية اللوبيا. أظهرت نتائج هذه الدراسة أن جميع انواع اللوبيا كان لها نفس العدان

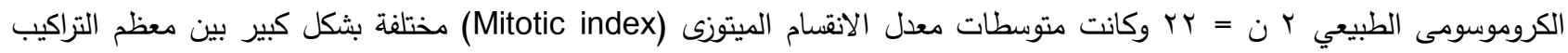

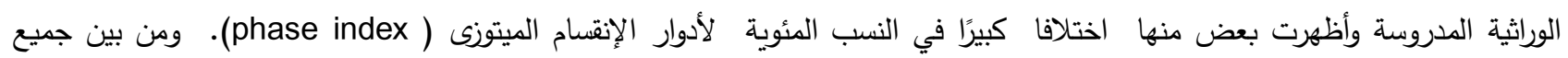

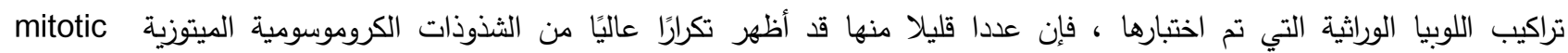

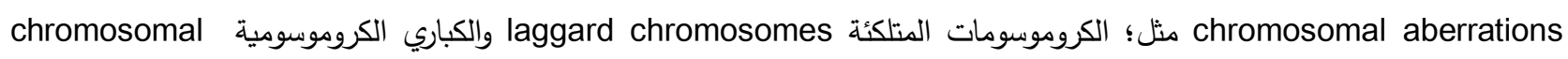

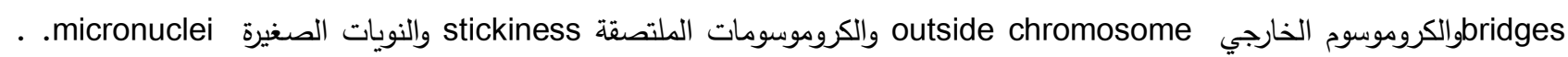
وكثفت النتائج الخلوية أن معظم التراكيب الوراثية من اللوبيا الدختبرة في هذه الدراسة لديها استقرار خلوي محتمل مع عدد كروموسومي طبيعي

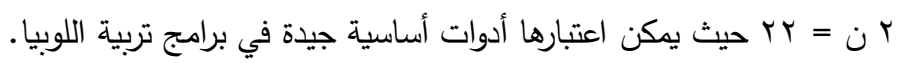

